\title{
The Bacterial Population of Neutral Mine Drainage Water of Elizabeth's Shaft (Slovinky, Slovakia)
}

\author{
Jana Kisková ${ }^{\cdot}$ Zuzana Perháčová ${ }^{\cdot}$ Ladislav Vlčko² $^{2}$ Jana Sedláková $^{1} \cdot$ Simona Kvasnová ${ }^{3} \cdot$ Peter Pristaš $^{1,4}$
}

Received: 10 October 2017 / Accepted: 5 March 2018 / Published online: 12 March 2018

(c) The Author(s) 2018, corrected publication 2020

\begin{abstract}
Although neutral mine drainage is the less frequent subject of the interest than acid mine drainage, it can have adverse environmental effects caused mainly by precipitation of dissolved Fe. The aim of the study was to characterize the composition of bacterial population in environment with high concentration of iron and sulfur compounds represented by neutral mine drainage water of Elizabeth's shaft, Slovinky (Slovakia). Direct microscopic observations, cultivation methods, and 454 pyrosequencing of the 16S rRNA gene amplicons were used to examine the bacterial population. Microscopic observations identified iron-oxidizing Proteobacteria of the genera Gallionella and Leptothrix which occurrence was not changed during the years 2008-2014. Using 454 pyrosequencing, there were identified members of 204 bacterial genera that belonged to 25 phyla. Proteobacteria (69.55\%), followed by Chloroflexi (10.31\%) and Actinobacteria (4.24\%) dominated the bacterial community. Genera Azotobacter (24.52\%) and Pseudomonas (14.15\%), followed by iron-oxidizing Proteobacteria Dechloromonas (11\%) and Methyloversatilis (8.53\%) were most abundant within bacterial community. Typical sulfur bacteria were detected with lower frequency, e.g., Desulfobacteraceae $(0.25 \%)$, Desulfovibrionaceae $(0.16 \%)$, or Desulfobulbaceae $(0.11 \%)$. Our data indicate that the composition of bacterial community of the Elizabeth's shaft drainage water reflects observed neutral $\mathrm{pH}$, high level of iron and sulfur ions in this aquatic habitat.
\end{abstract}

\section{Introduction}

Studies of the diversity of microorganisms inhabiting extreme environments have increased significantly over the past years. These environments were far more widespread during the early life of our planet and organisms isolated from these sites are representative of archaic life forms.

Electronic supplementary material The online version of this article (https://doi.org/10.1007/s00284-018-1472-6) contains supplementary material, which is available to authorized users.

Jana Kisková

jana.kiskova@upjs.sk

1 Institute of Biology and Ecology, Faculty of Science, Pavol Jozef Šafárik University in Košice, 04154 Košice, Slovakia

2 Department of Biology and General Ecology, Faculty of Ecology and Environmental Sciences, Technical University in Zvolen, 96053 Zvolen, Slovakia

3 Department of Biology and Ecology, Faculty of Natural Science, Matej Bel University, 97401 Banská Bystrica, Slovakia

4 Institute of Animal Physiology, Centre of Biosciences of Slovak Academy of Sciences, 04101 Košice, Slovakia
Extremophiles as living organisms or as sources of enzymes and other cell products offer a wide range of applications in a variety of industrial and biotechnological operations also in medicine [1].

Mining activities and ore processing result in irreversible changes in landscape in the form of heaps and sewage sludge beds of waste material. These deposits are permanent source of toxic substances, especially heavy metals which contaminate all environmental compounds, mainly soil and water. Changes of water and soil quality affect also biodiversity of mining area [2-5]. The properties of drainage water depend on many factors, including mineralogical, geochemical properties, hydrogeological conditions, and the activity of lithoautotrophic microorganisms. Oxidative dissolution of sulfide minerals generates acidity and releases sulfate, iron, and associated metals to pore waters. This phenomenon is known as acid mine drainage (AMD). However, neutral mine drainage (NMD) conditions may persist in an abundance of carbonate minerals [6-9]. Principal threats to water quality under circumneutral $\mathrm{pH}$ conditions are weakly hydrolysing metals, including $\mathrm{Fe}, \mathrm{Ni}, \mathrm{Cu}$, and $\mathrm{Zn}$ [10]. While mechanisms of sulfide mineral oxidation in AMD and bacteria 
participating in are well established, there are limited data on microbiota of NMD settings.

Slovinky mining area (north part of Slovak Ore Mountains territory, Spišská Nová Ves district, Slovakia) is considered the largest source of copper ores in Slovak region (chalcopyrite, cuprite, malachite, delafossite) but it is also rich in iron ores (siderite, pyrite, chalcopyrite, delafossite). The most frequent secondary and tertiary minerals are iron oxides such as goethite or crystalline hydrous ferric oxide [11]. Mining in Slovinky was stopped in 1999 but due to sludge bed vulnerability represent high-risk area threatening all environmental components (soil, water, living organisms). The mine dumps are near-neutral or slightly alkaline (pH 7.2-8.8) because the acidity generated by the decomposition of the sulfide ores is efficiently neutralized by the abundant carbonate minerals [2, 11]. Elizabeth's shaft was built in 1900 and it works as mining drainage water system. Sulfide minerals exposed by mining and erosion are unstable in the presence of atmospheric oxygen and water; the resulting oxidation of sulfides can release sulfate and iron ions into the drainage water [8]. Regular monitoring of physicochemicals parameters of mine drainage water demonstrated that an average iron concentration did not exceed $0.5 \mathrm{mg} / \mathrm{l}$ for many years. In addition, a high concentration of $\mathrm{SO}_{4}$, $\mathrm{Mn}, \mathrm{As}$, and Sb have been long-term monitored [12]. Based on these characteristics, we assumed a high incidence of iron and sulfur bacteria within bacterial community in drainage water.

Iron bacteria represent heterogeneous group belonging to many different phyla (e.g., Proteobacteria, Firmicutes, Nitrospirae) which can be divided into several groups based on their physiological properties and the role in ferrous ion oxidation [13]. Originally, iron bacteria were considered to catalyze the oxidation of iron II ( $\mathrm{Fe}^{2+}$, ferrous iron) to iron III $\left(\mathrm{Fe}^{3+}\right.$, ferric iron). More recently, bacteria catalyzing the reduction of ferric to ferrous ion have been also included in iron bacteria [14]. Gallionella ferruginea is probably the oldest known iron-oxidizing bacterium [15]. The bacterium was first discovered in the ochre mineral deposit and to date Gallionella-related species were found in many various soil and aquatic habitats, always associated with iron. Gallionella spp. is one of the most commonly detected bacteria in acid mine environments [16]. Leptothrix spp. are heterotrophic $\mathrm{Fe} / \mathrm{Mn}$-oxidizing inhabitant of aqueous environments, especially characterized by a circumneutral $\mathrm{pH}$ to slightly acidic, an oxygen gradient and a source of reduced $\mathrm{Fe}$ and Mn minerals [17]. Both of iron-oxidizing bacterial genera are characterized by biogenically formed various iron oxyhydroxide structures. Gallionella spp. are characterized by stalk and particulates formation; Leptothrix spp. by typical sheaths easily recognized by light microscopy $[14,18-21]$.
Sulfur bacteria represent a diverse group of microorganisms capable of metabolizing sulfur and its compounds [22]. However, in most environments (particularly in the sub-surface) few bacterial species, or combination of species, probably carry out iron and organic carbon oxidation, carbon and nitrogen fixation, extracellular polymeric slime production, as well as iron and sulfur reduction leading to the either to the AMD or NMD. Members of the genus Acidithiobacillus (particularly A. ferrooxidans) are frequently found in acid mine environments with high occurrence of iron-sulfur ores but less often under circumneutral to alkaline conditions. These bacteria oxidize sulfide minerals, resulting in ferric ions and sulfuric acid production and acidification of the environment $[23,24]$.

The original aim of this study was to examine the occurrence of iron-sulfur bacteria in a neutral mine drainage of Elizabeth's shaft using direct microscopy and cultivation methods and to investigate their seasonal dynamics over several years. Since some changes in $\mathrm{pH}$ of drainage water have been recorded during the period of investigation, we decided to analyze the structure of bacterial community in NMD using a high-throughput sequencing technique in order to detect bacteria that could contribute to (or responsible for) these changes.

\section{Materials and Methods}

\section{Sampling Site and Physico-Chemical Water Quality Indicators Measurements}

Mine drainage water samples were collected directly from the water flowing out from Elizabeth's shaft in Slovinky

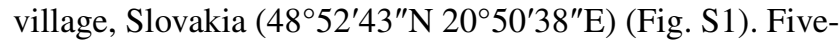
hundred microliters of water was taken two times a year in the period from 2008 to 2011 (first week in March and October), and four times a year in the years 2012-2014 (first week in March, June, August, and October) into sterile bottles. The water was transported under cold, dark conditions to the laboratory. Physico-chemical parameters $(\mathrm{pH}$ and electric conductivity) were measured directly in the field with WTW Multi 340i instrument (WTW Gmbh, Weilheim, Germany) equipped with a $\mathrm{pH}$ electrode WTW Sen Tix 31-3 and standard WTW TetraCon 325 electrode for an electric conductivity (total dissolved solids, TDS) measurement.

\section{Direct Microscopic Observations and Cultivation-Based Analyses}

The light microscope Olympus BX 40 equipped with digital camera was used for quantitative and qualitative assessment of abioseston and bioseston in mine drainage water samples. 
First, $10 \mathrm{ml}$ water from each sample was taken into 50-ml centrifuge tube with conical bottom and centrifuged at $2000 \mathrm{~g}$ for $5 \mathrm{~min}$. Subsequently, supernatant was removed and sample was spin down briefly to remove drops from the inside of the tube. A small water drop was taken by Pasteur pipette, placed into Cyrus chamber and examined by light microscopy. Bacteria determination was performed according to Švorcová's [25] and Tóthová and Mogoňová's [26] instructions. Relative abundance of abioseston and bioseston fraction was expressed by the percentage of coverage of the ten different microscopic fields at $\times 1000$ total magnifications [26].

The selective medium proposed by Švorcová [25] was used to detect subpopulation of selected iron bacteria $\left(\left(\mathrm{NH}_{4}\right)_{2} \mathrm{SO}_{4}, \mathrm{NaNO}_{3}, \mathrm{~K}_{2} \mathrm{HPO}_{4} \cdot 3 \mathrm{H}_{2} \mathrm{O}\right.$, and $\mathrm{MgSO}_{4} \cdot 7 \mathrm{H}_{2} \mathrm{O}$ each of $0.5 \mathrm{~g}, 3 \mathrm{~g}$ of $\mathrm{FeSO}_{4}, 10 \mathrm{~g}$ sodium citrate, $2 \mathrm{~g}$ of sucrose, $1 \mathrm{~g}$ tryptose, $20 \mathrm{~g}$ agarose, distilled water add into total volume of $11, \mathrm{pH} 6.8)$. Components were dissolved in distilled water and sterilized at $100{ }^{\circ} \mathrm{C}$ for $30 \mathrm{~min}$ by fractional sterilization (three consecutive days in flowing water). One hundred microliters of drainage water was spread directly onto solid medium and cultivated at $25^{\circ} \mathrm{C}$ for 3 days. Obtained bacterial colonies were picked up by a sterile microbial loop, stained using Gram's method and examined by light microscopy.

To detect the presence of iron-sulfur oxidizing bacteria of the genus Acidithiobacillus, the water samples $(1 \mathrm{ml})$ were inoculated into $50 \mathrm{ml}$ of liquid Thiobacillus Broth (HiMedia, Mumbai, India) and cultivated aerobically at $25^{\circ} \mathrm{C}$ until turbidity developed. Serial dilution of the culture was then spread on the solid Thiobacillus Agar (HiMedia, Mumbai, India) and cultivated at $25{ }^{\circ} \mathrm{C}$ for 3 days. Also cultivation of water samples was carried out at $30{ }^{\circ} \mathrm{C}$ for $3-4$ days in a standard $9 \mathrm{~K}$ medium [27].

Non-parametrical Kruskal-Wallis test (one-way ANOVA) was used to analyze the changes in physico-chemical parameters and occurrence of iron bacteria and/or other microorganisms detected by microscopic observation during the period of investigation.

\section{DNA Isolation, Bacterial 16S rDNA PCR Amplification and 454 Pyrosequencing}

In March 2014, a high-throughput sequencing analysis of $16 \mathrm{~S}$ rRNA gene was performed in the order to better understand the composition of bacterial community in drainage water of Elizabeth's shaft.

One hundred millilitres of the drainage water was centrifuged at $3000 \mathrm{~g}$ for $20 \mathrm{~min}$ and the total metagenomic DNA was extracted from the pellet using the GenElute ${ }^{\mathrm{TM}}$ Bacterial Genomic DNA Kit (Sigma-Aldrich, St. Louis, USA). The quality of DNA was checked by agarose gel electrophoresis.
The bacterial barcoding was performed using universal primers (fwd: 5'-TAGAGTTTGATYMTGGCTCAG-3' and rev: 5'-GWATTACCGCGGCKGCTG-3') to amplify an approximately $500 \mathrm{bp}$ fragment consisting of the hypervariable V1-V3 region of the $16 \mathrm{~S}$ rRNA gene [28, 29]. Primers were modified by the addition of a GS FLX Titanium Series adapter sequences A and B (A: CCATCTCATCCCTGC GTGTCTCCGAC and B: CCTATCCCCTGTGTGCCTTGG CAGTC) and four-base library "key" sequence (TCAG). Multiplex identifier (MID) sequence specifying this sample was incorporated into the forward primer (ACTATACGAG).

PCR reaction mixture consisted of $0.1 \mu$ of Phire ${ }^{\circ}$ Hot Start II DNA Polymerase (Finnzymes Oy, Espoo, Finland), 0,2 mM dNTPs (Metabion, Martinsried, Germany), $1 \times$ Phire Reaction Buffer, 10 pmol of each primer and 40-80 ng of DNA template in a final volume of $20 \mu \mathrm{l}$. The PCR conditions consisted of initial denaturation step of $95^{\circ} \mathrm{C}$ for 3 min followed by 35 cycles of $93{ }^{\circ} \mathrm{C}$ for $60 \mathrm{~s}, 50{ }^{\circ} \mathrm{C}$ for $60 \mathrm{~s}$, and $72{ }^{\circ} \mathrm{C}$ for 70 and a final extension step of $72{ }^{\circ} \mathrm{C}$ for 5 min (C1000 Thermal Cycler, Bio-Rad Laboratories $\mathrm{GmbH}$, München, Germany). PCR product was checked for correct size on a $1 \%$ agarose gel, purified with Wizard® SV Gel and PCR Clean-Up System (Promega, Madison, USA). The next generation 454 pyrosequencing was performed using Roche 454 GS-FLX Titanium instrument (LaRoche, USA) and reagents according to the manufacturer's guidelines. Demultiplexed raw reads generated in this study have been deposited in the NCBI Sequence Read Archive with the Bioproject accession number PRJNA324333.

\section{Processing of 454 Data}

DNA sequencing data were processed using the Mothur bioinformatics software package (version 1.36.1) [30].

First, flow gram file was produced from the standard flow gram file (sff) using "sffinfo" command. The resulting flow gram file was trimmed using "trim.flows." Flow grams differed $>2$ bases from primer sequence and $>1$ base from barcode were discarded. The flow gram file was denoised using "shhh.flows" as Mothur's implementation of PyroNoise algorithm [31]. After denoising, adapters, barcodes, and primers were trimmed from sequences ("trim.seqs"). Sequences of low quality (average quality score $<0.25$ ), shorter than $200 \mathrm{bp}$, containing ambiguously determined nucleotides and homopolymer $($ maximum $=8)$ with $>2$ base-difference from primer and $>1$ base-difference from barcode were excluded from further analysis. Trimmed sequences were aligned (align.seqs) against the Silva database (silva.seed_v123) [32]. Chimeric sequences were filtered out using Uchime algorithm implemented in Mothur (chimera.uchime) [33]. Obtained high-quality non-chimeras sequences were processed using Mothur's pipeline (unique. seqs, remove.lineage, filter.seqs, unique.seqs, dist.seqs) and 
after that they were clustered into operational taxonomic units (OTUs) with a 97\% similarity threshold ("cluster" command) using the average neighbor method. OTUs represented by a single sequence were excluded from the following analysis. Representative sequence of each OTU, produced using "get.oturep" command, was assigned by RDP Classifier at the confidence level of $>0.80$ (http://rdp.cme. msu.edu) [34].

\section{Results}

\section{Physico-Chemical Parameters and Direct Microscopic Observations}

Direct microscopic observations of water samples showed that the abioseston (percentage of coverage ranged from 8.0 to $10 \%$ ) was dominated by iron and manganese clots with occasional occurrence of dead plant tissues parts and other organic residues (such as pollen, insect wings etc.). Diatoms of genera Nitzschia, Navicula, and Eunotia were dominant group of bioseston (percentage of coverage ranged from 2.5 to $3.5 \%$ ). Iron bacteria in the drainage waters of Elizabeth's shaft were represented by a relatively small number (percentage of coverage ranged from 1.0 to $2 \%$ ) (Table 1). One group of iron bacteria was determined as of Gallionella spp. forming stalks and particules characteristic for Gallionella ferruginea. Another group of iron bacteria was determined as Leptothrix spp. based on the presence of a dominant sheath typical for Leptothrix ochracea (Fig. 1).

Cultivation analysis on the selective medium according to Švorcová [25] confirmed the presence of Ferribacterium species in each sampling during the period of investigation. Bacterial colonies were rusty with a white border or rust-shiny gold. Gram staining and microscopic observation shown the presence of small gram-negative rod-shaped,

Table 1 Physico-chemicals parameters and microscopic observation of abioseston and bioseston of mine drainage water from Elizabeth's shaft measured in the years 2008-2014 (Slovinky, Slovakia)

\begin{tabular}{|c|c|c|c|c|c|c|c|c|}
\hline Years & $2008(n=2)$ & $2009(n=2)$ & $2010(n=2)$ & $2011(n=2)$ & $2012(n=4)$ & $2013(n=4)$ & $2014(n=4)$ & $P$ value \\
\hline $\mathrm{pH}^{\mathrm{a}}$ & $7.1 \pm 0.3$ & $7 \pm 0.1$ & $6.9 \pm 0.1$ & $6.9 \pm 0.3$ & $6.8 \pm 0.3$ & $6.7 \pm 0.2$ & $6.5 \pm 0.2$ & $>0.05$ \\
\hline $\mathrm{EC}[\mathrm{mS} / \mathrm{m}]^{\mathrm{a}}$ & $42 \pm 1.4$ & $50 \pm 1.4$ & $49 \pm 4.2$ & $54 \pm 2.8$ & $57.3 \pm 2.3$ & $61.5 \pm 1.3$ & $63.5 \pm 1.3$ & $<0.001$ \\
\hline TDS [mg/l] ${ }^{\mathrm{a}}$ & $172 \pm 2.8$ & $181 \pm 1.4$ & $185 \pm 2.8$ & $198 \pm 4.2$ & $201.5 \pm 3.1$ & $200.3 \pm 1.7$ & $220.3 \pm 2.6$ & $<0.001$ \\
\hline Abioseston $^{\mathrm{b}}$ & $10 \pm 1.4$ & $9.5 \pm 0.7$ & $9.5 \pm 0.7$ & $9.5 \pm 0.7$ & $8.5 \pm 2.4$ & $8.0 \pm 1.8$ & $8.5 \pm 1.7$ & $>0.05$ \\
\hline Diatoms $^{\mathrm{b}}$ & $3.5 \pm 0.7$ & $3.5 \pm 0.7$ & $3 \pm 0.0$ & $4.0 \pm 1.4$ & $3 \pm 1.2$ & $2.5 \pm 1.3$ & $3 \pm 0.8$ & $>0.05$ \\
\hline Gallionella spp. $^{\text {b }}$ & $1 \pm 0.0$ & $2 \pm 0.0$ & $1 \pm 0.0$ & $1 \pm 0.0$ & $1.5 \pm 0.7$ & $1 \pm 0.0$ & $1 \pm 0.0$ & $>0.05$ \\
\hline Leptothrix spp. ${ }^{\mathrm{b}}$ & $1 \pm 0.0$ & $2 \pm 0.0$ & $2 \pm 0.0$ & $2 \pm 0.0$ & $1 \pm 0.0$ & $1.5 \pm 0.7$ & $1 \pm 0.0$ & $>0.05$ \\
\hline
\end{tabular}

$E C$ electric conductivity, TDS total dissolved solids, $P$ value result of Kruskal-Wallis test (one-way ANOVA)

${ }^{a}$ Values are expressed as arithmetic mean value \pm standard deviation of measurements in a given year $(n)$

${ }^{b}$ Values are expressed as arithmetic mean value \pm standard deviation of the percentage of coverage of 10 different microscopic fields measurements in a given year $(n)$
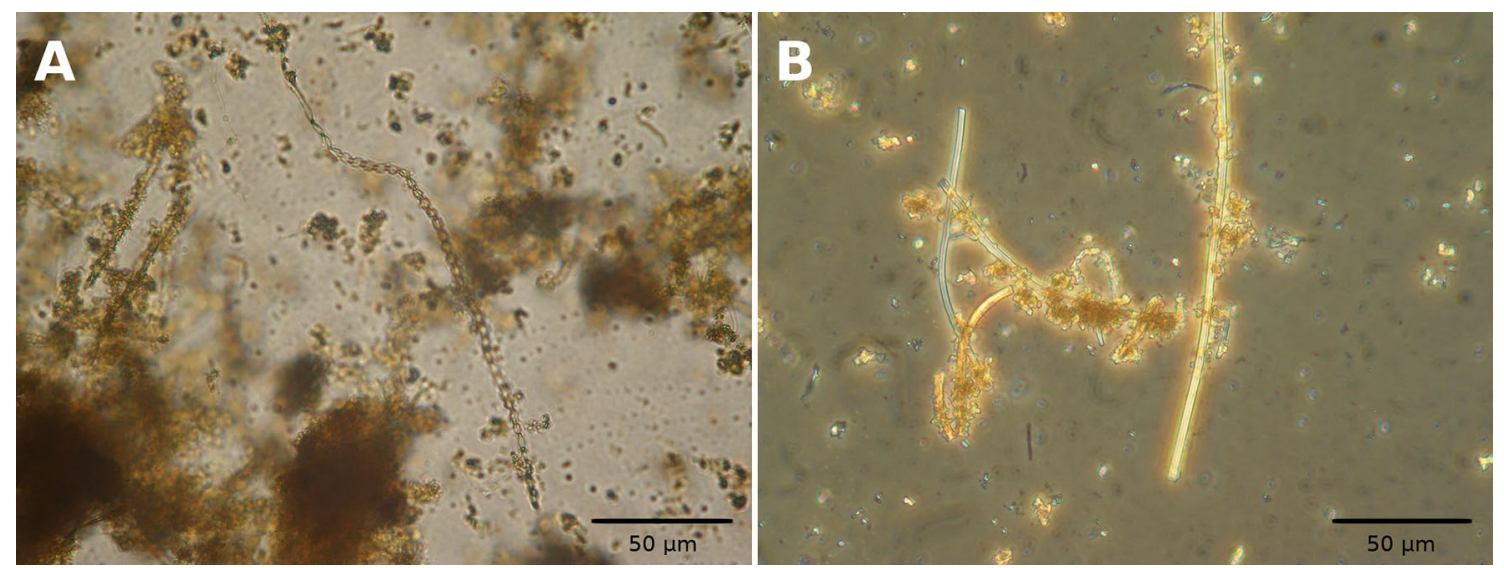

Fig. 1 Gallionella spp. (a) and Leptothrix spp. (b) observed in mine drainage water of Elizabeth's shaft (Slovinky, Slovakia). Microscopic observation at $\times 1000$ total magnification 
elliptical cells living in pairs or chains with surface coated by gelatinous pouch or thin capsule. These characteristics are typical for the bacteria of Ferribacterium genus [26, 35]. Cultivation using the selective Thiobacillus agar and 9K medium did not evidence the presence of bacteria belonging to Acidithiobacillus spp. in any sample.

During the years 2008-2014, the salinity (TDS) of Elizabeth's shaft drainage water significantly increased from 172 to $220.25 \mathrm{mg} / \mathrm{l}(\mathrm{pH}<0.001)$ and $\mathrm{pH}$ value slightly degreased from 7.1 to $6.5(P>0.05)$ but these changes did not affect the incidence of observed bacteria, resp. diatoms (Table 1).

\section{Bacterial Communities Recovered by 454 Pyrosequencing}

After trimming, denoising, quality, and length filtering and removing chimeras, a total of 7095 high-quality sequences were obtained. Sequences were clustered into 813 OTUs, while 414 were non-singletons (Table S1). One OTU was classified as Archaea, phylum Aigarchaeota (represented by two sequences). Other sequences were classified into 22 known bacterial phyla and three candidate phyla. The majority of sequences belonged to Proteobacteria (69.55\%) followed by Chloroflexi (10.31\%), Actinobacteria (4.24\%), Planctomycetes (2.57\%), Acidobacteria (2.35\%), and Verrucomicrobia (2.14\%). Other phyla were represented by less than $2 \%$ sequences (Fig. 2).

Bacteria were divided into three groups according to RDP classification (Table S2). The first group included 175 genera with known taxonomy (6645 sequences, 329 OTUs). The second group was represented by 394 sequences ( 75 OTUs) successfully assigned to known phyla but with unknown classification into other taxonomic levels (such as class, order, family). The third group included 54 sequences (9 OTUs) classified into three candidate phyla. Genus Azotobacter was most abundant genus (24.52\%) followed by

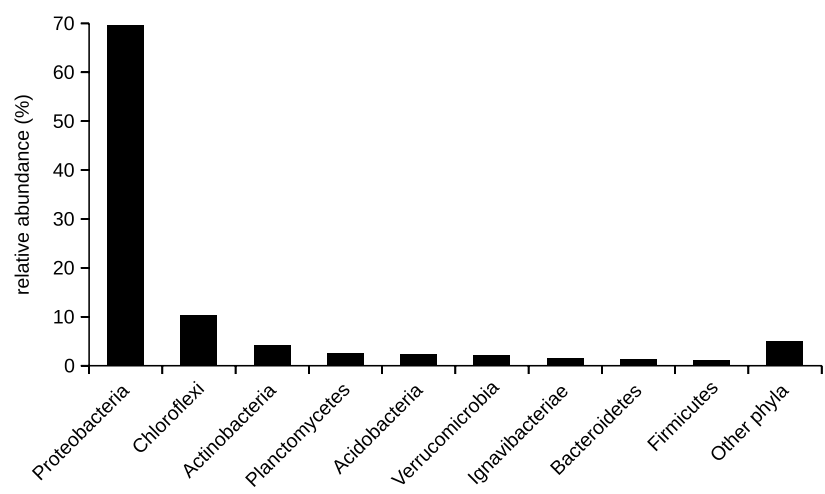

Fig. 2 Bacterial composition at the phylogenetic phylum level of mine drainage water of Elizabeth's shaft (Slovinky, Slovakia). The category "Other phyla" groups bacterial phyla whose relative abundance was below $1 \%$
Pseudomonas (14.15\%), Dechloromonas (11\%), Methyloversatilis $(8.53 \%)$, and Bellilinea (5.46\%). Other genera were represented by less than $5 \%$ of sequences (Fig. 3).

We detected numerous members of iron and sulfur bacteria group (Table 2). Proteobacteria such as Dechloromonas spp. (11\%) and Ferribacterium spp. (1.73\%) dominated within iron bacteria. Other most abundant iron bacteria were Chloroflexi such as Bellilinea spp. (5.46\%), Longilinea spp. (1.93\%), and Leptolinea spp. (1.54\%). Sulfur bacteria were represented by members of families Desulfobacteraceae $(0.25 \%)$, Desulfovibrionaceae $(0.16 \%)$, or Desulfobulbaceae

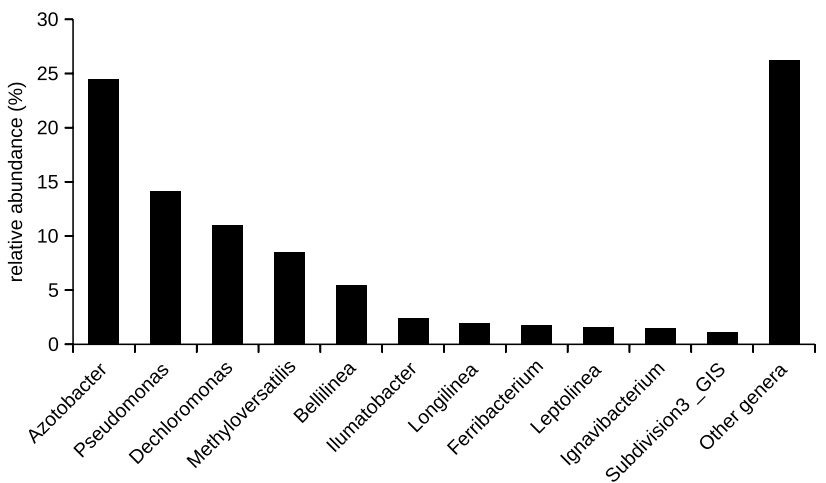

Fig. 3 Bacterial composition at the phylogenetic genus level of mine drainage water of Elizabeth's shaft (Slovinky, Slovakia). The category "Other genera" groups bacterial genera whose relative abundance was below $1 \%$

Table 2 Representatives of iron and sulfur bacteria in mine drainage water of Elizabeth's shaft (Slovinky, Slovakia)

\begin{tabular}{|c|c|c|c|}
\hline Phylum & Taxonomic affiliation & Nr. of reads & $\begin{array}{l}\text { Relative } \\
\text { abundance } \\
\%\end{array}$ \\
\hline Actinobacteria & Rhodococcus spp. & 30 & 0.42 \\
\hline Chloroflexi & Bellilinea spp. & 387 & 5.46 \\
\hline Chloroflexi & Leptolinea spp. & 109 & 1.54 \\
\hline Chloroflexi & Longilinea spp. & 137 & 1.93 \\
\hline Proteobacteria & Acidiferrobacter spp. & 17 & 0.24 \\
\hline Proteobacteria & Bilophila spp. & 11 & 0.16 \\
\hline Proteobacteria & Desulfatiferula spp. & 8 & 0.11 \\
\hline Proteobacteria & Desulfospira spp. & 7 & 0.10 \\
\hline Proteobacteria & Dechloromonas spp. & 780 & 11.00 \\
\hline Proteobacteria & Ferribacterium spp. & 123 & 1.73 \\
\hline Proteobacteria & Leptothrix spp. & 13 & 0.18 \\
\hline Proteobacteria & Geobacter spp. & 9 & 0.13 \\
\hline Proteobacteria & Geopsychrobacter spp. & 8 & 0.11 \\
\hline Proteobacteria & Sulfuritalea spp. & 15 & 0.21 \\
\hline Proteobacteria & Thiobacter spp. & 6 & 0.08 \\
\hline Proteobacteria & Thiococcus spp. & 12 & 0.17 \\
\hline Proteobacteria & Thiofaba spp. & 13 & 0.18 \\
\hline Proteobacteria & Thiothrix spp. & 6 & 0.08 \\
\hline
\end{tabular}


$(0.11 \%)$ or the genera such as Acidiferrobacter $(0.24 \%$, Ectothiorhodospiraceae), Sulfuritalea (0.21\%, Rhodocyclaceae), Thiofaba $(0.18 \%$, Halothiobacillaceae) or Thiococcus $(0.17 \%$, Chromatiaceae). In addition, Zoogloea spp. as very important bacterium from the family Rhodocyclaceae $(0.42 \%)$ was detected (Table 2$)$.

Complete bacterial classification according to RDP database (http://rdp.cme.msu.edu) is shown as a supplementary material in ESM3.xlsx file.

\section{Discussion}

One of the most critical issues in mine environments is the natural oxidation (chemical and biological) of sulfide mineral tailings that are exposed to water, oxygen, and microorganisms. This oxidation is responsible for the generation of mine drainage that compromises the quality of soil, surface water, and sub-surface water bodies, hence affecting overall biodiversity [2-5].

Despite expectations, direct microscopic observations and the high-throughput analysis have shown a low abundance of Gallionella spp. and Leptothrix spp. Even Gallionella spp. was not detected by 454 pyrosequencing. The low occurrence of these bacteria may be due to preference for more acidic conditions as well as other environmental factors (e.g., heavy metals).

Ferribacterium is a genus of the family Rhodocyclaceae and up to now, only one species is known (F. limneticum). This bacterium belongs to $\mathrm{Fe}(\mathrm{III})$-reducing bacteria and was first isolated from mining-impacted fresh lake sediments containing heavy metals such as $\mathrm{Fe}, \mathrm{Pb}, \mathrm{Zn}$, or $\mathrm{As}$ [36]. Its presence in drainage water of Elizabeth's shaft was confirmed by cultivation as well as 454 pyrosequencing.

Acidithiobacillus species was detected neither by cultivation methods nor by 454 pyrosequencing. These findings confirmed the preference of the genus Acidithiobacillus of acidic environment, despite the high sulfur and iron content in neutral mine drainage water.

The chemistry of mine drainage is the result of the competing processes of acid formation and neutralization [37]. Several mine discharges are characterized by a circumneutral $\mathrm{pH}$ due to either an absence of pyrite within the ore, hence minimizing the acid generating potential on site, or due to the presence of a carbonate minerals as a calcite, which effectively neutralize any acidity produced [11]. Drainage water flowing from Elizabeth's shaft is characterized by high concentration of iron, manganese, arsenic, and sulfate ions [12]. Concentration of copper and zinc did not overexpress limit values according of Regulation of the Government of the Slovak Republic [38]. Continual increase of TDS concentration is probably due to the gradual release of metal(loid)s during sulfide mineral oxidation and bacterial metabolic activity. The Elizabeth's shaft drainage water could be defined as circumneutral, since acid generated via sulfide mineral oxidation (e.g., pyrite or chalcopyrite) is neutralized by the dissolution of carbonate minerals as siderite or malachite. On the other side, our results indicate a slight shift to the acidic $\mathrm{pH}$ during the examined period. Slow reduction of $\mathrm{pH}$ of drainage water is supported by earlier studies demonstrating $\mathrm{pH}$ value of 8.24 in 1999 and 7.56 in 2000 [39].

Therefore, we performed an analysis of the bacterial community using a high-throughput sequencing technique to find out bacteria that could be involved in reducing $\mathrm{pH}$ of drainage water. Generally, Proteobacteria, Nitrospirae, Actinobacteria, and Firmicutes are most frequently detected phyla in AMD [6, 24, 40]. Proteobacteria, Deinococcus/ Thermus, Gemmatimonadetes, Acidobacteria, and Actinobacteria were found with high frequency also in neutral mine drainage [3, 41]. While lithotrophic genera such as Acidithiobacillus, Acidiphilum, Ferrovum, Leptospirillum, Gallionella, and Sulfobacillus dominate AMD environments [6, 24, 40], heterotrophic Proteobacteria such as Pseudomonas spp., Bacillus spp., and Stenotrophomonas spp. were found with high abundance in neutral copper mine drainage [42] and other mining samples [43, 44]. The high abundance of Pseudomonas spp. was also confirmed in our study. Members belonging to the genus Pseudomonas are characterized by great deal of metabolic diversity and they are able to colonize a wide range of environments. A number of studies have been demonstrated its resistance to heavy metals and its capability to degrade a wide range of pollutants [45, 46].

Pereira et al. [3] assumed that the abundance of tolerant bacteria in areas of extreme environmental conditions increases, while that of more sensitive microorganisms decreases. Previous studies have reported that AMD is accompanied by low bacterial diversity $[6,47]$. In contrast, a wide range of different bacteria including iron-oxidizing and heterotrophic organisms were found in slightly alkaline French mine sediments [48] and alkaline river sediments contaminated with heavy metals released from Brazilian arsenic mine [49]. Analysis of microbial composition of wastewater of Elizabeth's shaft showed a trend to increase the abundance of tolerant bacteria leading to a reduction of the total bacterial diversity. Proteobacteria represent almost $70 \%$ of the total diversity of bacterial community. These bacteria have been found to be predominant phylum in many mine environments indicating the high adaptability of members to extreme mining environments $[3,48,49]$.

Free-living motile bacteria of the genus Azotobacter dominate bacterial community in wastewater of Elizabeth's shaft. These bacteria were found mainly in neutral soil and aquatic environments and they are capable of atmospheric nitrogen fixation due to iron requiring enzymatic system and can survive in contaminated environments by heavy metals. 
Thus, isolates resistant to heavy metals could be employed in bioremediation processes [50-52].

Interestingly, genus Methyloversatilis (Nitrosomonadales, Sterolibacteriaceae) showed relatively high abundance (8.53\%) within bacterial population in this study. Recently, only few species belonging to this genus have been found in natural and human-made ecosystems [53-56]. Genus was detected with low frequency in alkaline mountaintop mine drainage in Central Appalachian streams [57].

Rhodocyclales, Rhizobiales, Rhodobacterales, and Rhodospirillales formed relatively large group within Proteobacteria. Many members of these taxa exhibit very versatile metabolic capabilities allowing them survive under various extreme environmental conditions [22]. They were found with high frequency in neutral mine drainage [41], in slightly alkaline mine sediments [48] as well as in AMD [24]. In this study, the highest number of sequences was affiliated to the genus Dechloromonas. These bacteria are known as nitratedependent neutrophilic iron-oxidizers and perchlorate reducer [58]. Bacteria belonging to this genus were found in soil high concentration of iron also in circumneutral or slightly acidic mine waters contaminated by many different heavy metals $[59,60]$. Bacteria of the genus Zoogloea, member of the family Rhodocyclaceae, were known as activated sludge bacteria responsible for flock formation in activated sludge and are used in waste water purification processes [61].

Members of the phylum Chloroflexi are frequently detected in polluted environments $[62,63]$. The phylum with the predominant family Anaerolineaceae represents about 10\% diversity of bacterial community in this study. Similarly, phylum showed a high abundance in alkaline river sediments contaminated with heavy metals [49] and in neutral copper mine drainage [3], but was not detected in AMD [24].

While sulfate-reducing bacteria have been commonly identified in tailings deposits and sulfide mine wastes [7, 64], representatives of this bacterial group (Desulfobacterales, Desulfovibrionales, Desulfuromonadales, and Syntrophobacterales) were detected with relative low frequency in this study. In addition, typical sulfur-oxidizing bacteria (e.g., Acidiferrobacter spp. Thiofaba spp., Thiococcus spp.) were found with low abundance.

Although high-throughput sequencing techniques offer an efficient way to access the microbial community in different environments, several studies have been also demonstrated that bacteria represented rare taxa within bacterial community could not be detected at the sequencing depth [65-67]. Similarly, we did not detected Gallionella spp. by 454 pyrosequencing. Moreover, culture-independent methods bring not important information about bacterial pathogenicity, antimicrobial resistance or production of metabolites and enzymes [66]. In practice, only cultivable microorganisms can be effectively used in industrial and biotechnological operations (e.g., bioremediation processes). Therefore, combination of culture-independent and culture-dependent methods is important in bacterial community investigations.

In addition to bacteria, genera of diatoms Nitzschia spp., Navicula spp. and Eunotia spp. were observed with high abundance in drainage water. Diatoms, as one of the dominant components of phytoplankton, are widely distributed in freshwater and marine ecosystems. They respond quickly to environmental changes therefore are popular tool for monitoring water quality. Many studies on metal polluted aquatic ecosystems have shown that diatoms respond through shifts in dominant taxa also at the individual level with changes in frustule morphology [68-70]. Several species belonging to the genera Nitzschia spp., Navicula spp. and Eunotia spp. were detected as dominant or with high abundance within bacterial communities in water samples from mining areas. These areas, similarly to Slovinky mining area, are characterized by the high occurrence of various iron and copper ores and high concentration of $\mathrm{Fe}, \mathrm{Cu}, \mathrm{Pb}, \mathrm{Cr}, \mathrm{Zn}$, and other heavy metals in flowing rivers $[69,70]$.

In conclusion, relatively low abundance of typical ironand sulfur-bacteria in microbial community indicates that in addition to high concentration of iron and sulfur, other environmental factors significantly affect the composition of bacterial community and bacterial species with a great metabolic diversity dominate among bacteria. The $\mathrm{pH}$ of the drainage water is still nearly neutral, however we detected slightly shift to acidic. Sulfide mineral oxidation and possibly metabolic activity of iron/sulfur oxidizers could lead to the continual decrease of $\mathrm{pH}$ and to the deterioration of environmental impact of mine drainage of Elizabeth's shaft. Monitoring of the $\mathrm{pH}$ value continues and any changes in the bacterial community will be verified by further metagenomic analysis.

Acknowledgements This work was supported in part by grants provided by Ministry of Education, Science, Research and Sport of the Slovak Republic (VEGA 1/0229/17), Pavol Jozef Šafárik University in Košice (VVGS-2016-275) and H2020-MSCA-RISE-2016-CHARMED under Grant Agreement No. 734684.

Open Access This article is licensed under a Creative Commons Attribution 4.0 International License, which permits use, sharing, adaptation, distribution and reproduction in any medium or format, as long as you give appropriate credit to the original author(s) and the source, provide a link to the Creative Commons licence, and indicate if changes were made. The images or other third party material in this article are included in the article's Creative Commons licence, unless indicated otherwise in a credit line to the material. If material is not included in the article's Creative Commons licence and your intended use is not permitted by statutory regulation or exceeds the permitted use, you will need to obtain permission directly from the copyright holder. To view a copy of this licence, visit http://creativecommons.org/licenses/by/4.0/

\section{Compliance with Ethical Standards}

Conflict of interest The authors declare that they have no conflict of interest. 


\section{References}

1. Anitori RP (2012) Extremophiles: microbiology and biotechnology. Caister Academic Press, Poole

2. Angelovičová L, Bobul'ská L, Fazekašová D (2015) Toxicity of heavy metals to soil biological and chemical properties in conditions of environmentally polluted area middle Spiš (Slovakia). Carpath J Earth Env 10(1):193-201

3. Pereira LB, Vicentini R, Ottoboni LMM (2014) Changes in the bacterial community of soil from a neutral mine drainage channel. PLoS ONE 9(5):e96605

4. Sasaki K, Lesbarreres D, Beaulieu CT, Watson G, Litzgus J (2016) Effects of mining-altered environment on individual fitness of amphibians and reptiles. Ecosphere 7(6):e01360

5. Xu X, Cai H, Sun D, Hu L, Banson K (2016) Impacts of mining and urbanization on the Qin-Ba Mountainous environment, China. Sustainability 8(5):488

6. Kuang JL, Huang LN, Chen LX, Hua ZS, Li SJ, Hu M, Li JT, Shu WS (2013) Contemporary environmental variation determines microbial diversity patterns in acid mine drainage. ISME J 7(5):1038-1050

7. Lindsay MBJ, Condon PD, Jambor JL, Lear KG, Blowes DW, Ptacek CJ (2009) Mineralogical, geochemical and microbial investigation of a sulfide-rich deposit characterized by neutral drainage. Appl Geochem 24(12):2212-2221

8. Lindsay MBJ, Moncur MC, Bain JG, Jambor JL, Ptacek CJ, Blowes DW (2015) Geochemical and mineralogical aspect of sulfide mine tailings. Appl Geochem 57:157-177

9. Majzlan J, Lalinská B, Chovan M, Bläß U, Brecht B, Göttlicher J, Steininger R, Hug K, Ziegler S, Geschler J (2011) A mineralogical, geochemical, and microbiological assessment of the antimony- and arsenic-rich neutral mine drainage tailings near Pezinok, Slovakia. Am Mineral 96(1):1-13

10. Scharer JM, Pettit CM, Kirkaldy JL, Bolduc L, Halbert BE, Chambers DB (2000) Leaching of metals from sulphide mine wastes at neutral pH In: ICARD 2000 Proceedings from the Fifth International Conference on Acid Rock Drainage, Vol I. Society for Mining, Metallurgy, and Exploration, Inc., Englewood, pp 191-201

11. Kucerova G, Majzlan J, Lalinska-Volekova B, Radková A, Bačík P, Michňová J, Sottník P, Jurkovič L', Klimko T, Steininger R, Göttlicher J (2014) Mineralogy of neutral mine drainage in the tailings of sidetite-Cu ores in Eastern Slovakia. Can Mineral 52(5):779-798

12. Bajtoš $P$, Mašlár E, Mašlárová I (2015) Mining impact on the environment. State Geological Institute of Dionýz Štúr, Spišská Nová Ves

13. Hedrich S, Schlömann M, Johnson DB (2001) The iron-oxidizing proteobacteria. Microbiology 157(Pt 6):551-1564

14. Emerson D, Fleming GJ, McBeth JM (2010) Iron oxidizing bacteria: an environmental and genomic perspective. Annu Rev Microbiol 64:561-583

15. Ehrenberg CG (1836) Vorlaufige Mitteilungen über das wirkliche Vorkommen fossiler Infusorien and ihre grosse Verbreitung. Poggendorts Ann 38:213-227

16. Fabisch M, Beulig F, Akob DM, Küsel K (2013) Surprising abundance of Gallionella-related iron oxidizers in creek sediments at $\mathrm{pH} 4.4$ or at high heavy metal concentrations. Front Microbiol 4:390

17. Kunoh T, Kunoh H, Takada J (2015) Perspectives on the biogenesis of iron oxide complexes produced by Leptothrix, an ironoxidizing bacterium and promising industrial application for their functions. J Microb Biochem 7(6):419-426

18. Chan CS, Fakra SC, Emerson D, Fleming EJ, Edwards KJ (2011) Lithotrophic iron-oxidizing bacteria produce organic stalks to control mineral growth: implications for biosignature formation. ISME J 5(4):717-727
19. Fleming EJ, Langdon AE, Martinez-Garcia M, Stepanauskas R, Poulton NJ, Masland ED, Emerson D (2011) What's new is old: resolving the identity of Leptothrix ochracea using single cell genomics pyrosequencing and FISH. PLoS ONE 6(3):e17769

20. Li D, Li Z, Yu J, Cao N, Liu R, Yang M (2010) Characterization of bacterial community structure in a drinking water distribution system during an occurrence of red water. Appl Environ Microbiol 76(21):7171-7180

21. van Veen WL, Mulder EG, Deinema MH (1978) The Sphaerotilus-Leptothrix group of bacteria. Microbiol Rev 42(2):329:356

22. Frigaard NU, Dahl C (2009) Sulfur metabolism in phototrophic sulfur bacteria. Adv Microb Physiol 54:103-200

23. Cohen RRH (2006) Use of microbes for cost reduction of metal removal from metals and mining industry waste streams. J Cleaner Prod 14(12-13): 1146-1157

24. Kadnikov VV, Ivasenko DA, Beletsky AV, Mardanov V, Danilova EV, Pimenov NV, Karnachuk OV, Ravin NV (2016) Effect of metal concentration on the microbial community in acid mine drainage of a polysulfide ore deposit. Microbiology 85(6):745-751

25. Švorcová L (1985) Cultivation and detection of iron and manganese bacteria in water. In Proceedings: Water Microbiology. Water Research Institute, Bratislava, pp 48-55

26. Tóthová L, Mogoňová E (2000) Iron and manganese bacteria. Water Research Institute, Bratislava

27. Silverman MP, Lundgren DS (1959) Studies of the chemoautotrophic iron bacterium Ferrobacillus ferrooxidans. An improved medium and a harvesting procedure for securing high cells yields. J Bacteriol 77:642-647

28. Frank JA, Reich CI, Sharma S, Weisbaum JS, Wilson BA, Olsen GJ (2008) Critical evaluation of two primers commonly used for amplification of bacterial 16S rRNA genes. Appl Environ Microbiol 74(8):2461-2470

29. Lane DJ, Pace B, Olsen GJ, Stahl DA, Sogin ML, Pace NR (1985) Rapid determination of $16 \mathrm{~S}$ ribosomal RNA sequences for phylogenetic analyses. Proc Natl Acad Sci USA 85(20):6955-6959

30. Schloss PD, Westcott SL, Ryabin T, Hall JR, Hartmann M, Holliste EB, Lesniewski RA, Oakley BB, Parks DH, Robinson CJ, Sahl JW, Stres B, Thallinger GG, Van Horn DJ, Weber CF (2009) Introducing mothur: open-source, platform-independent, community-supported software for describing and comparing microbial communities. Appl Environ Microbiol 75(23):7537-7541

31. Quince C, Lanzén A, Curtis TP, Davenport RJ, Hall N, Head IM, Read LF, Sloan WT (2009) Accurate determination of microbial diversity from 454 pyrosequencing data. Nat Methods 6(9):639

32. Quast C, Pruesse E, Yilmaz P, Gerken J, Schweer T, Yarza P, Peplies J, Glöckner FO (2013) The SILVA ribosomal RNA gene database project: improved data processing and web-based tools. Nucl Acids Res 41(Database issue):D590-D596

33. Edgar RC, Haas BJ, Clemente JC, Quince C, Knight R (2011) UCHIME improves sensitivity and speed of chimera detection. Bioinformatics 27(16):2194-2200

34. Wang Q, Garrity GM, Tiedje JM, Cole JR (2007) Naïve Bayesian classifier for rapid assignment of rRNA sequences into the new bacterial taxonomy. Appl Environ Microbiol 73(16):5261-5267

35. Cullimore DR, McCann AE (1978) The identification, cultivation and control of iron bacteria in ground water. In: Skinner FA, Shewan JM (eds) Aquatic microbiology. Academic Press, New York, pp 219-261

36. Cummings DE, Caccavo F, Spring S, Rosenzweig RF (1999) Ferribacterium limneticum, gen. nov., sp. nov., an Fe(III)-reducing microorganism isolated from mining-impacted freshwater lake sediments. Arch Microbiol 171(3):183-188

37. Seal RR, Hammarstrom II JM (2003) Geoenvironmental models of mineral deposits - Examples from massive sulfide and gold deposits. In: Jambor JL, Blowes DW, Ritchie AIM (eds) 
Environmental aspects of mine wastes: short-course series 31 . Mineralogical Association of Canada, Quebec, pp 11-50

38. Luptakova A, Prascakova M, Kotulicova I (2012) Occurrence of Acidithiobacillus ferrooxidans bacteria in sulfide mineral deposits of Slovak republic. Chem Engineer Trans 28:31-36

39. Bajtoš P, Záhorová L' (2007) Monitoring of environmental impacts in the hazardous areas of magnesite, talc and ore deposits extraction. State Geological Institute of Dionýz Štúr, Spišská Nová Ves

40. Travisany D, Di Genova A, Sepulveda A, Bobadilla-Fazzini RA, Parada P, Maass A (2012) Draft genome sequence of the Sulfobacillus thermosulfidooxidans Cutipay strain, an indigenous bacterium isolated from a naturally extreme mining environment in Northern Chile. J Bacteriol 194(22):6327-6328

41. Pereira LB, Vicentini R, Ottoboni LMM (2015) Characterization of the core microbiota of the drainage and surrounding soil of a Brazilian copper mine. Genet Mol Biol 38(4):484-489

42. da Costa BZ, Rodrigues VD, de Oliveira VM, Ottoboni LMM, Marsaioli AJ (2016) Enzymatic potential of heterotrophic bacteria from a neutral copper mine drainage. Braz J Microbiol 47(4):846-852

43. Choudhary S, Sar P (2011) Uranium biomineralization by a resistant Pseudomonas aeruginosa strain isolated from contaminated mine waste. J Hazard Mater 186(1):336-343

44. Freitas DB, Lima-Bittencourt CI, Reis MP, Costa PS, Assis PS, Chartone-Souza E, Nascimento AM (2008) Molecular characterization of early colonizer bacteria from wastes in a steel plant. Lett Appl Microbiol 47(4):241-249

45. Kumar R, Nongkhlaw M, Acharya C, Joshi SR (2013) Growth media composition and heavy metal tolerance behaviour of bacteria characterized from the sub-surface soil of uranium rich ore bearing site of Domiasiat in Meghalaya. Indian J Biotechnol 12(1):115-119

46. Naz T, Khan MD, Ahmed I, Rehman SU, Rha ES, Malook I, Jamil M (2016) Biosorption of heavy metals by Pseudomonas species isolated from sugar industry. Toxicol Ind Health 32(9):1619-1627

47. Bruneel O, Duran R, Casiot C, Elbaz-Poulichet F, Personné J-C (2006) Diversity of microorganisms in Fe-As-rich acid mine drainage waters of Carnoule's, France. Appl Environ Microb 72(1):551-556

48. Halter D, Cordi A, Gribaldo S, Gallien S, Goulhen-Chollet F, Heinrich-Salmeron A, Carapito C, Pagnout C, Montaut D, Seby F, Van Dorsselaer A, Schaeffer C, Bertin PN, Bauda P, ArsènePloetze F (2001) Taxonomic and functional prokaryote diversity in mildly arsenic-contaminated sediments. Res Microbiol 162(9):877-887

49. Reis MP, Barbosa FAR, Chartone-Souza E, Nascimento AM (2013) The prokaryotic community of a historically miningimpacted tropical stream sediment is as diverse as that from a pristine stream sediment. Extremophiles 17(2):301-309

50. Abo-Amer AE, Abu-gharbia MA, Soltan EM, El-Raheem WM (2014) Metal-resistant Azotobacter chroococuum from agricultural soil and their potential application in bioremediation. Geomicrobiol J 31(7):551-561

51. Bellenger JP, Wichard T, Xu T, Kraepiel AM (2011) Essential metals for nitrogen fixation in a free-living $\mathrm{N}_{2}$-fixing bacterium: chelation, homeostasis and high use efficiency. Environ Microbiol 13(6):1395-1411

52. Noumsi CJ, Pourhassan N, Darnajoux R, Deicke M, Wichard T, Burrus V, Bellenge JP (2016) Effect of organic matter on nitrogenase metal cofactors homeostasis in Azotobacter vinelandii under diazotrophic conditions. Environ Microbiol Rep 8(1):76-84

53. Cai T, Qian L, Cai S, Chen L (2011) Biodegradation of benazolinethyl by strain Methyloversatilis sp. cd-1 isolated from activated sludge. Curr Microbiol 62(2):570-577

54. Doronina NV, Kaparullina EN, Trotsenko YA (2014) Methyloversatilis thermotolerans sp. nov., a novel thermotolerant facultative methylotroph isolated from a hot spring. Int J Syst Evol Microbiol 64(Pt 1):158-164

55. Jiao S, Liu Z, Lin Y, Yang J, Chen W, Wei G (2016) Bacterial communities in oil contaminated soils: biogeography and cooccurrence patterns. Soil Biol Biochem 98:64-73

56. Smalley NE, Taipale S, De Marco P, Doronina NV, Kyrpides N, Shapiro N, Woyke T, Kalyuzhnaya MG (2015) Functional and genomic diversity of methylotrophic Rhodocyclaceae: description of Methyloversatilis discipulorum sp. nov. Int J Syst Evol Microbiol 65(7):2227-2233

57. Bier RL, Voss KA, Bernhardt ES (2015) Bacterial community responses to a gradient of alkaline mountaintop mine drainage in Central Appalachian streams. ISME J 9(6):1378-1390

58. Chakraborty A, Picardal F (2013) Induction of Nitrate-Dependent $\mathrm{Fe}(\mathrm{II})$ Oxidation by $\mathrm{Fe}(\mathrm{II})$ in Dechloromonas sp. Strain UWNR4 and Acidovorax sp. strain 2AN. Appl Environ Microbiol 79(2):748-752

59. Drewniak L, Krawczyk PS, Mielnicki S, Adamska D, Sobczak A, Lipinski L, Burec-Drewniak W, Sklodowska A (2016) Physiological and metagenomic analyses of microbial mats involved in self-purification of mine waters contaminated with heavy metals. Front Microbiol 7:1252

60. Watanabe T, Sumida H, Do NM, Yano K, Asakawa S, Kimura M (2013) Bacterial consortia in iron-deposited colonies formed on paddy soil surface under microaerobic conditions. Soil Sci Plant Nutr 59(3):337-346

61. Shao Y, Chung BS, Lee SS, Park W, Lee S-S, Jeon CO (2009) Zoogloea caeni sp. nov., a floc-forming bacterium isolated from activated sludge. Int J Syst Evol Microbiol 59(Pt 3):526-530

62. Liu Y, Dong Q, Shi H (2015) Distribution and population structure characteristics of microorganisms in urban sewage system. Appl Microbiol Biotechnol 99(18):7723-7734

63. Yamada T, Sekiguchi Y (2009) Cultivation of uncultured Chloroflexi subphyla: significance and ecophysiology of formerly uncultured Chloroflexi "subphylum I" with natural and biotechnological relevance. Microb Environ 24(3):205-216

64. Schippers A, Breuker A, Blazejak A, Bosecker K, Kock D, Wright TL (2010) The biogeochemistry and microbiology of sulfidic mine waste and bioleaching dumps and heaps, and novel Fe(II)-oxidizing bacteria. Hydrometallurgy 104(3-4):342-350

65. Shade A, Hogan CS, Klimowicz AK, Linske M, McManus PS, Handelsman J (2012) Culturing captures members of the soil rare biosphere. Environ Microbiol 14(9):2247-2252

66. Stefani FO, Bell TH, Marchand C, de la Providencia IE, Yassimi AE, St-Arnaud M, Hijri M (2015) Culture-dependent and -independent methods capture different microbial community fractions in hydrocarbon-contaminated soils. PLoS ONE 10(6):e0128272

67. Vaz-Moreira I, Egas C, Nunes OC, Manaia CM (2011) Culturedependent and culture-independent diversity surveys target different bacteria: a case study in a freshwater sample. Antonie Van Leeuwenhoek 100(2):245-257

68. Cattaneo A, Couillard Y, Wunsam S, Courcelles M (2004) Diatom taxonomic and morphological changes as indicators of metal pollution and recovery in Lac Dufault (Québec, Canada). J Paleolimnol 32(2):163-175

69. Ferreira da Silva E, Almeida SF, Nunes ML, Luís AT, Borg F, Hedlund M, de Sá CM, Patinha C, Teixeira P (2009) Heavy metal pollution downstream the abandoned Coval da Mó mine (Portugal) and associated effects on epilithic diatom communities. Sci Total Environ 407(21):5620-5636

70. Luís AT, Teixeira P, Almeida SFP, Matos JX, da Silva EF (2009) Environmental impact of mining activities in the Lousal area (Portugal): chemical and diatom characterization of metal-contaminated stream sediments and surface water of Corona stream. Sci Total Environ 409(20):4312-4325 